\title{
Styly vedení školy a sociální klima učitelských sborů základních škol ${ }^{1}$
}

\author{
Andrea Rozkovcová, Jitka Novotová \\ Technická univerzita v Liberci, Fakulta přírodovědně-humanitní a pedagogická
}

\begin{abstract}
Abstrakt: Kvalitativní studie představuje v úvodu nejčastěji vymezované styly vedení školy prezentované převážně $v$ zahraniční literatuře výzkumného i přehledového charakteru. Teorie stylů vedení školy slouží jako teoretický rámec pro interpretaci výsledků našeho výzkumu realizovaného ve třech českých školách s extrémními hodnotami sociálního klimatu učitelského sboru. $\mathrm{K}$ nalezení odpovědí na otázku: Jaké styly vedení se vyskytují ve vybraných školách s extrémními parametry sociálního klimatu učitelských sborů? - byl použit výzkumný přístup případové studie formou rozhovorů s vybranými učiteli, s vedeními škol, dále focus group s vybranými žáky a rozbor výročních zpráv a dalších dokumentů škol. Výsledky výzkumu ukazují na rozmanitost stylů vedení, jejich projevů a dopadů na sociální klima sborů. Jako významný faktor tvorby klimatu jsme identifikovaly charakteristiky ředitele - zda je učiteli vnímán jako součást sboru, chová-li se, jak vyžaduje od učitelů, a do jaké míry učitele kontroluje a podporuje $v$ jejich práci. V oblasti vztahu ředitele $\mathrm{k}$ učitelům byly jako důležité identifikovány vzájemná důvěra, spolupráce a respekt $\mathrm{k}$ názorové diverzitě.
\end{abstract}

Klíčová slova: styly vedení školy, leadership, klima učitelských sborů, případová studie

\section{Leadership Styles and the Social Climate of Basic School Teaching Staffs}

Abstract: The research study introduces the most often defined leadership styles in schools presented in foreign professional research and theoretical literature which serve as a theoretical frame for the interpretation of the results of the qualitative research realized in three Czech basic schools. The aim of the qualitative research was to find out which leadership styles are used in schools with extreme parameters of the social climate of the school teaching staff. The case study approach was used, specifically interviews with leaders of the selected schools, and with carefully selected teachers, focus groups with school students and analysis of school documentation. The research shows diversity of styles and the impact on the social climate. The principal has been identified as a significant factor in creating social climate of the teaching staff. Is the principal perceived as a part of the staff? Does he or she behave the same way that they demand from the teachers? Are teachers controlled and/or do they get support from the principal? Mutual trust, cooperation and respect to opinion diversity were identified as very important factors in the relationship between the principal and the teachers.

Keywords: school leadership styles, leadership, social climate of the teaching staffs, case study

1 Příspěvek je jedním z výstupů výzkumného projektu (GA ČR 16-10057S) „Stabilita a proměny učitelských sborů Ž̌ “a byl podpořen GA ČR. Autorky děkují za podporu. distribution, and reproduction in any medium, provided the original author and source are credited. 
68 Téma managementu a leadershipu čili řízení a vedení ve škole již bylo několika autory, jak uvádíme dále, v České republice rozpracováváno. Tato stat' přináší jiný pohled na oblast řízení a vedení ve škole, a to $v$ souvislosti s námi zkoumaným tématem sociálního klimatu učitelských sborů v českých základních školách. Styl vedení školy se podle výzkumných zjištění ukazuje jedním z hlavních faktorů ovlivňujících sociální klima učitelských sborů (Urbánek, Dvořák, \& Starý, 2014). Cílem naší studie je čtenáři zprostředkovat výsledky kvalitativního šetření klimatu učitelských sborů $v$ souvislosti se styly vedení $\vee$ českých základních školách. Nejprve představíme $v$ přehledu styly vedení, které jsme nalezly především v zahraniční literatuře britské a americké provenience z oblasti obecné teorie řízení i teorií vztahujících se př́mo ke školskému managementu. Zaměříme se na styly vedení, jež jsou často popisovány $v$ zahraniční literatuře ke školskému managementu a které jsme identifikovaly při našem kvalitativním šetření ve výzkumném vzorku tří škol. Zajímalo nás, které charakteristiky vedení a řízení školy, jakým způsobem a v jakém kontextu ovlivňují sociální klima ve sborech těchto škol. Vybrány byly školy, které vykazovaly př́znivé i nepř́znivé parametry sociálního klimatu učitelských sborů a zároveň odlišný styl vedení. V článku se pokusíme najít odpověd’ na výzkumnou otázku, jaké styly vedení se vyskytují ve vybraných školách s extrémními parametry sociálního klimatu učitelských sborů.

\section{Pojmy vedení a řízení školy a řešená výzkumná témata}

Terminologie týkající se vedení a ř́zení školy je vymezována zejména v triádě pojmů a souborủ aktivit vedení - řízení - správa školy (např. Pol, 2007a, 2007b). Hovoříme-li v textu o „vedení školy“, máme na mysli osoby, které jsou ve škole odpovědné za její rízení a vedení. Pokud hovoříme o procesech, pak obvykle používáme samostatné termíny „vedeni“ nebo „řizeni““. Společně s Polem chápeme pod termínem „ř́zeni““ procesy spjaté spíše se „zvládáním každodennosti a jejích nároků“ (2007a, s. 214), zatímco pod termínem „vedení“ procesy zaměřené na rozvoj lidí a na inovace $v$ organizaci. Řízení je základní dovedností vedení školy, bez kterého nemůže škola jako organizace fungovat. Organizace školy může dočasně fungovat s limitovanými procesy vedení, nikoli však s chybějícím řízením. Klasifikace stylů vedení školy v zahraniční literatuře, zvláště po roce 2000 , však již nevykazují tuto dlouhodobě převažující pojmovou dichotomii, ale obsahují v daném pojetí vedení vždy obě tyto složky. Spíše než vymezování specifik a oddělování procesủ vedení a řízení je v současných zahraničních př́stupech pozornost věnována výzkumům a konceptualizaci procesů, jako jsou volba prístupu vedení školy k zaměstnancům (Harris \& Chapman, 2002), organizační učení (Leithwood \& Riehl, 2003; Vanblaere \& Devos, 2016), význam týmů zkušených učitelů (senior teachers) pro soudržnost učitelských sborů (Bush \& Glover, 2012), distribuce moci v organizaci (Harris, 2003, 2004; Bush \& Glover, 2012; Lumby, 2013) nebo vliv kontextových faktorů na styl vedení (Van- 
derhaar, Muñoz, \& Rodosky, 2007), které lépe postihují podstatu procesů spjatých $s$ vedením a řízením. $V$ našem textu budeme proto $v$ souladu se zahraničními trendy použivat pojem vedení (leadership) $\vee$ tomto komplexním pojetí integrujícím dílčí procesy vedení a řízení.

V české pedagogice je po roce 2000 v souvislosti s procesy vedení školy ve výzkumech pozornost zaměřena především na kulturu školy (Pol et al., 2005), profesní vývoj ředitelů (Pol et al., 2010), strategie vedení (Sedláček, 2011), klima učitelských sborů (Urbánek et al., 2014) nebo na školu jako učící se organizaci (Pol et al., 2013; Šed'ová et al., 2016). V naší studii cílíme na podrobnější probádání souvislostí mezi charakteristikami vedení a klimatem učitelského sboru. Chceme zjistit, jaké styly vedení převažují ve školách, $v$ nichž klima sborovny vykazuje nepříznivé charakteristiky, a naopak, jaké styly vedení se uplatňují ve škole s výbornou kvalitou klimatu sboru.

\section{Nejčastěji vymezované styly vedení školy v zahraniční literatuře}

Při sestavování přehledu stylů vedení ve škole vycházíme ze studií výzkumného i přehledového charakteru publikovaných po roce 2000 , výjimečně i starších stěžejních textů, abychom postihly i chronologický vývoj př́stupů $k$ této problematice. Výčet stylů vedení $v$ tomto textu není zcela vyčerpávající. Naše členění obsahuje čtyři styly, které podle množství dostupných zdrojů a obliby autorů je konceptualizovat a operacionalizovat pro výzkum nazýváme jako „klasické“ - instruktivní, transformativní, manažerský a distributivní. Dále analyzujeme styly demokratický a „vyvážený“ (balaced leadership), jež do jisté míry prvky z předchozích stylů kombinují.

\subsection{Instruktivní vedení alias vedení zaměřené na kvalitu vyučování (instructional leadership)}

Instruktivní vedení bylo nejčastějším konceptem pro výzkumy $v$ oblasti vedení školy v letech 1980-1995 (Hallinger \& Heck, 1996). Ukazuje se, že je velmi funkční, pokud jde o školy, které jsou zaměřeny na zlepšování vzdělávacích výsledků žáků a na zkvalitňování procesů učení a vyučování (srov. Rhodes \& Brundrett, 2010). Dobře se uplatňuje $v$ menších školách, $v$ nichž si vedení školy může dovolit strávit mnoho času ve tř́dách a pomáhat se zaváděním kurikula nebo zlepšováním vyučovacích procesů. Hallinger (2003) uvádí, že významnost tohoto stylu vedení vychází z výzkumu zavádění změn, zlepšování školy a jejího programu, a to především ve školách, které potřebovaly zásadní změny (byly to chudé městské školy, jak uvádí autor). Instruktivní vedení se zaměřuje zejména na tvorbu kurikula, koordinaci, kontrolu, supervizi a rozvíjení kvalitního vyučování ve škole. Instruktivní vedení školy je vnímáno jako silné a direktivní, nebot' změny ve škole jsou určovány shora, vedením. Je postaveno na charismatu a expertize ředitelů a jejich schopnostech 
70 podpořit procesy změny. Problémem tohoto stylu může být, že učitelé někdy bývají většími experty na procesy učení a vyučování než vedení školy. Někteří kritikové tohoto stylu vyjadřují názor, že vést školu po stránce administrativní i pedagogické je pro ředitele úkol nemožný až nadlidský (in Hallinger, 2003). Belgičané Vanblaere a Devos (2016) ve své studii zdůvodňují, že pokud je instruktivní vedení školy spojeno s transformativním vedením, jsou vytvořeny optimální podmínky, aby se škola stala učící se organizací.

\subsection{Transformativní vedení (transformational leadership)}

Tento styl vedení je rozpracováván v literatuře týkající se obecné teorie vedení od sedmdesátých a v literatuře školského managementu od osmdesátých let 20. století. První významnou prací o školství byla Bassova studie (1985), již po dvaceti letech revidují a obohacují autoři Leithwood a Jantziová (2005), kteří vypracovali přehledovou studii výzkumů $\mathrm{k}$ transformativnímu vedení za období let 1996-2005. Transformativní vedení je podle nich určeno následujícími komponentami týkajícími se několika oblastí - určování směru organizace (stanovování vizí, sdílení společných cílů a vysoká očekávání z hlediska výkonu), pomoc lidem (individualizovaná podpora, intelektuální stimulace a modelování klíčových hodnot a praxe), proměny organizace (budování kultury organizace a tvorba struktur napomáhajících spolupráci, budování produktivních vztahů s rodiči a komunitou) a management organizace.

Podle Kirkbridea (2006) jsou transformativní lídři schopni individualizovaného zvažování a ohleduplnosti k zaměstnancům, dokážou naslouchat, jsou ochotni nechat zaměstnance pracovat na jejich vlastních projektech a uznávají odlišnost názorů a pojetí, z nichž se dokážou i učit. Intelektuální stimulace je stěžejním aspektem kreativních procesů v organizaci. Díky ní lze proměňovat paradigmata, premisy a předpoklady. Další strategie transformativního vedoucího zahrnují dovednost motivovat zaměstnance skrze jasné a konkrétní cíle a optimistický př́stup k budoucnosti organizace. Transformativní vedoucí se pro své následovníky stává vzorem, mívá charisma. Nicméně je to silný vedoucí a moc je stále převážně v jeho rukou.

\subsection{Manažerské vedení (managerial leadership)}

Tento styl vedení v češtině stále spíše označujeme pojmem „ř́zení školy“. Vedoucí pracovníci jsou zaměřeni na zvládání běžné operativy, dokážou racionálně zvládat většinu funkcí školy. Tento přistup $k$ vedení je primárně založen na přísném dodržování pravidel a jasném a pevném stanovování úkolů a cílů. Škola je řízena v hierarchické struktuře, $v$ níž vedoucí pracovníci využívají své pozice pro rozhodování a uplatňování někdy i mocenských praktik, opírajíce se o politická rozhodnutí. Chybí akcent $\mathrm{k}$ budování mezilidských vztahů a v př́padě přehnané snahy o efektivitu a dodržování všech předpisů, např. pomocí přebujelé administrativy, se tento styl vedení popisuje jako manažerismus (Bush \& Glover, 2014). Pol popisuje manažerismus jako nevhodný způsob vyrovnávání se s problémy organizace a doslova říká: 
Manažerismus je chyba, k níž se obvykle uchylujeme, když nám schází síla, znalost či invence jít správným směrem, věnovat se dưležitým věcem (strategii, budoucnosti) a dobře zvládat to skutečně aktuálně důležité... (Pol, 2007a, s. 35)

Zřetelně vyvstává chybění vizí, hodnot a expertizy vedení školy. Toto kritizují Bush a Glover (2014) a uvádějí, že manažerské vedení je pro úspěšnou školu zásadní, ale mělo by doplňovat, nikoli nahrazovat, př́stupy založené na hodnotách. Manažerismus je tedy krajní a odborníky negativně hodnocenou formou manažerského vedení.

\subsection{Distributivní vedení (distributed leadership)}

Podle Bushe (2013) je distributivní model nejvhodnější volbou pro vedení školy v 21. století. Distributivní vedení je charakteristické svým rozdělením mezi více aktérů. Lze je nazvat „sdíleným“ vedením, kdy každý člen vedení nebo vedoucí tým má své pravomoci, které nesdílí s ostatními, ale uplatňuje je samostatně. $V$ tomto stylu jsou tedy využívány expertní kompetence zaměstnanců. Koncept distributivního vedení je postaven na myšlence, že „vedení může vyvstat kdekoli v organizaci a není omezeno na jednu formálně ustanovenou osobu“ (tamtéž). Bush a Glover (2012, 2014) představují distributivní styl vedení jako převažující ve školách s nejlepšími týmy. Shrnují, že nejlepší kombinací pro úspěšné vedení školy jsou styly manažerský a distributivně instruktivní. Srovnáme-li tento názor s autory Vanblaerem a Devosem (2016), kteři jako vhodnou kombinaci uvedli styly transformativní a distributivně instruktivní, pak je tu patrný rozdíl mezi akcentem na manažerské aktivity k udržení statu quo a akcentem na transformační aktivity směřující ke změnám.

Problém uplatnění distributivního stylu vedení ve školství je podle Hartleye (cit. dle Bush \& Glover, 2014, s. 560) formální struktura instituce školy, proto se tento styl neprosazuje ve školství snadno. Pro implementaci tohoto stylu do praxe je důležité, aby učitelé měli čas se scházet a měli s vedením školy dobré a neohrožující vztahy. To potvrzuje také Harrisová (2005) poukazujíc na stěžejní podmínku kvalitního klimatu ve sboru a ve vedení školy. Bolden (2011) upozorňuje na riziko protichůdných cílů při distribuci moci na více lídrů v jedné organizaci. Výzkumy dopadu distributivního stylu vedení na vzdělávací výsledky přinášejí nejednoznačné výsledky (srov. York-Barr \& Duke, 2004, cit. podle Bolden, 2011; Day at al., 2009).

\subsection{Demokratické (na lidi orientované) vedení (democratic, or people-centred leadership)}

Tímto názvem Harrisová (Harris \& Chapman, 2002) souhrnně označuje vybrané stěžejní faktory úspěšného vedení. Kvalitativní výzkum Harrisové a Chapmana v deseti školách, které se potýkaly $s$ vážnějšími obtížemi, odhalil, že ředitelé k prosazení trvalých a dlouhodobých změn těchto škol považují za zásadní distribuovat moc a předat kompetence učitelům (tzv. teacher empowerment). Tento proces autoři výzkumu vnímají jako demokratický. Pro demokratické vedení jsou dále stěžejní 
72 hodnoty jako rovnost (equity) a morální účel jednání (moral purpose). Tyto hodnoty se $v$ procesu změn ve zkoumaných školách neměnily, zatímco konkrétní opatření ano. Jako zásadní se jeví sdílení vizí a hodnot $v$ organizaci, rozdělení vedení, investice do rozvoje zaměstnanců, budování mezilidských vztahů a školy jako učící se komunity. Důležité tedy je, aby všichni zaměstnanci hodnoty a vize znali, přijímali je nebo jim alespoň zásadně nevadily. $V$ procesu změny ředitelé investovali nejen do okamžitě prospěšných znalostí a dovedností zaměstnanců, ale také je motivovali tím, že se mohli rozvíjet podle svých potřeb. Svou otevřeností a schopností sebekritiky dokázali pozvednout vztahy s učiteli, ale i rodiči a žáky. Vytvoření učící se komunity vyžadovalo ve všech školách dlouhé diskuse a dialog mezi aktéry - vedením, zaměstnanci školy a rodiči. Tento styl vedení vzhledem $\mathrm{k}$ humanistickým hodnotám, na nichž je založen, bývá také nazýván people-centered leadership čili „na lidi orientované vedení“ (Harris \& Chapman, 2002).

\subsection{Vyvážené vedení (balanced leadership)}

Tento styl vedení je založen na teorii o změnách prvního a druhého řádu v organizacích, v našem prípadě ve škole. Waters a jeho spolupracovníci (Waters, Marzano, \& McNulty, 2003) uvádějí, že změny prvního řádu jsou cílené, jasně definovatelné, implementují se postupně a pravidelně, mohou být méně významné, okrajové, lze je implementovat pomocí současných znalostí a dovedností nebo s pomocí experta. Uskutečňují se totiž v rámci existujících paradigmat a vedou pouze $\mathrm{k}$ rozšíření „minulosti“. Změny druhého řádu naopak vyžadují změnu paradigmat, jsou v kontrastu s minulostí či „tradici“ školy, mohou být dokonce v konfliktu s dosavadními hodnotami a normami školy, rodí se pomalu, mohou být neohraničené a s nejasnými výsledky, nelineární, mohou představovat narušení systému, čili i ten je pak nutno přehodnocovat. Změny druhého řádu vyžadují nové znalosti a dovednosti, nejsou orientovány na řešení jasně specifického problému, bývají implementovány zainteresovanými osobami v organizaci (Waters, Marzano \& McNulty 2003). Úkolem vedoucího pracovníka či vedoucích pracovníků ve škole je tedy rozlišit, jakého druhu je změna, na kterou je třeba se zaměřit, a podle toho zvolit styl vedení. To vše samožrejmě při zvážení kontextu, ve kterém se škola nachází, a personální konstelace ve sboru.

Waters se spolupracovníky ve své studii (2003, s. 9-12) uvádějí 21 oblastí, za které je vedoucí pracovník školy odpovědný. Zatímco jen k některým z nich se vztahují změny prvního řádu, všechny jsou důležité pro realizaci změn druhého řádu. Při interpretaci výsledků našeho kvalitativního výzkumu se mimo jiné opíráme o tyto oblasti.

\section{Metodologie výzkumu}

Výsledky výzkumu, které zde prezentujeme, jsou dílčími výsledky tř́letého výzkumu v designu Quan - Qual - Quan v oblasti fluktuace učitelů a sociálního klimatu učitel- 
ských sborů v ČR, který je realizován výzkumným týmem šesti výzkumníků. V jeho první fázi, realizované ve školním roce 2015-2016, bylo klima učitelských sborů zkoumáno dotazníkem OCDQ-RS na reprezentativním vzorku náhodným výběrem zvolených základních škol $(N=125)$. Klima bylo měřeno $v$ dimenzích direktivity vedení, podpory od vedení, angažovanosti učitelů, frustrace učitelů a jejich vztahů - intimity. Tyto dimenze slouží k výpočtu tzv. indexu otevřenosti klimatu (Chvál \& Urbánek, 2014) a vnímáme je jako vymezující pro koncept sociálního klimatu učitelských sborů. Dle Hoye, Tartera a Kottkampa $(1991$, s. 33) jsou pro otevřené klima ve sboru charakteristické kolegiální přátelské vztahy postavené na důvěře a respektu, spolupráci, otevřené komunikaci a oddanosti práci. Ředitel naslouchá myšlenkám učitelů, často je chválí, odměňuje a podporuje, respektuje jejich kompetence a poskytuje jim svobodu pro jejich práci bez časté kontroly a byrokratických požadavků. Z pojmenovaných dimenzí plyne, že vedení hraje nezpochybnitelně významnou roli z hlediska utváření sociálního klimatu učitelských sborů (direktivita, podpora) a že si toho byli vědomi již tvůrci tohoto nástroje. Tyto myšlenky nás vedly $k$ formulaci hlavní výzkumné otázky pro následný dílči kvalitativní výzkum bliže popsaný v této studii (viz níže).

V druhé fázi výzkumu, ve školním roce 2016-2017, bylo pomocí shlukové analýzy vygenerováno pět skupin ZŠ s podobnými profily klimatu a z nich vybráno deset škol, $\checkmark$ nichž byly realizovány kvalitativní procedury (QL). $V$ každé škole bylo uskutečněno šest až dvanáct individuálních rozhovorů s vedením a vybranými učiteli a jedna ohnisková skupina s žáky. Jako pomocné metody byly využity pozorování ve vyučovacích hodinách (3-5 hodin), rozbor výročních zpráv a další školní dokumentace. Vzhledem k tomu, že kvalitativní výzkum probíhal $v$ deseti školách, interval zkoumání v každé škole byl v rozmezí dvou až tři dnů při účasti týmu tří až pěti výzkumníků.

Pro naši vícepř́padovou instrumentální studii (viz Mareš, 2015, s. 119, 121) byly kvưli rozsahu textu vybrány tři školy, typičtí zástupci základních škol v ČR, z nich dvě ze skupiny škol s nejhorším klimatem učitelského sboru a jedna ze skupiny škol s klimatem velmi dobrým. Z kvantitativního výzkumu vyplynulo, že na kvalitu sociálního klimatu učitelského sboru nemají zásadní vliv velikost školy ani obce, proto jsme při výběru vzorku tyto faktory nebraly $v$ potaz.

Dále byly stanoveny výzkumné otázky rưzné míry obecnosti (Mareš, 2015, s. 126). Nejobecnější otázka týkající se všech tří případových studií jako celku byla formulována takto: Jaké styly vedení se vyskytují ve vybraných školách s extrémními parametry sociálního klimatu učitelských sborů? Konkrétnější výzkumné otázky byly vytvořeny na základě dotazníku OCDQ-RS vymezujícího dimenze klimatu učitelského sboru. Jejich účelem bylo prohloubení porozumění výsledkům dotazníkového šetření a kontextu školy: Jak se učitelé zapojují do řizení a vedení školy? Jakým způsobem ředitel poskytuje podporu učitelům? Jak probíhá komunikace mezi vedením školy a učiteli? Jakým způsobem participují na chodu školy rodiče a žáci? Jak si respondenti vysvětlují naměřenou úroveň frustrace u učitelư? Jak si respondenti vysvětlují naměřenou úroveň angažovanosti učitelư? Jaké vztahy panují mezi učiteli a které faktory tyto vztahy ovlivňují? Nad rámec OCDQ-RS byly zformulovány otázky zjišt'ují- 
74 cí fázi a hloubku rozvoje školy: V jaké fázi změny se škola nachází? Jedná se o změny prvního nebo druhého řádu?

Z výzkumných otázek byly odvozeny konkrétní otázky pro polostrukturované rozhovory - zvlášt' pro učitele a zvlášt' pro vedení školy. Pro jejich tvorbu nám také jako pomocná metoda posloužila analýza výročních zpráv a webových stránek škol. Další metodologickou procedurou byla diskuse $s$ žáky $v$ ohniskové skupině. Bylo vybráno šest až osm žáků $z$ 8. a 9. ročníků s různým prospěchem, dívky i chlapci ve stejném poměru. Pro tyto skupiny byly vytvořeny otázky směřující k prozkoumání tématu klimatu učitelského sboru z žákovské perspektivy: Jaké pozorujete vztahy mezi učiteli? Jaká panuje kolegialita mezi učiteli? Jak se žáci podílejí na chodu školy?

Všechny rozhovory $v$ délce 30-60 minut byly nahrávány na diktafon a přepsány doslovně. Nejprve bylo použito otevřené kódování, kódy jsme vzájemně porovnávaly a tř́dily podle významu do kategorií. Na jejich základě jsme sestavily jednotlivé príiběhy (srov. Švařiček, Šed'ová, et al., 2007, s. 220-222). V dalším kroku jsme využily selektivní kódování a hledaly jsme hlavní témata a kategorie, z nichž jsme tvořily príběhy (srov. Hendl, 2005, s. 251-255). Př́běhy byly pro potřeby tohoto textu vzhledem $\mathrm{k}$ jeho omezenému rozsahu zestručněny. Uvádíme $v$ nich pouze hlavní témata vztahující se k cíli výzkumu.

\section{Přiběhy škol}

\subsection{ZŠ 066 - Škola s nepřijatým vedením (příklad školy s převážně manažeristickým vedením)}

Výzkumná škola vykazovala na základě kvantitativního šetření (rok 2016) extrémně nepř́znivé hodnoty sociálního klimatu učitelského sboru (124. pozice z $N=125$ ). Škola se nachází v obci s přibližně 2000 obyvateli pobliž velkého města. Má kolem 200 žáků a pracuje v ní 15 učitelů. Před šesti lety, v roce 2012, se ve zkoumané škole změnilo vedení. Současná ředitelka, stejně tak i zástupkyně, se rekrutovaly z pozic řadových učitelek této školy. Ředitelka si zástupkyni vybrala, když se ucházela o funkci ředitelky:

Ano, do konkurzu jsem už šla s tím, že musím mít vlastně po ruce pracovitého člověka, který by ty změny, které měly nastat, spolu se mnou zrealizoval. A paní zástupkyni znám jako kolegyni a hodně pracovitého člověka a my jsme takhle fungovaly jako učitelé, hodně... velký elán jsme měly do práce, tak jsem řekla: „To je ten pravý člověk, který mi to pomůže zrealizovat."

Ředitelka k situaci školy před jejím nástupem do funkce říká:

A tady ta škola vlastně byla na tý fázi, že se chodilo vlastně po vyučování... jsme zavřeli dveře a nebyly akce pro rodiče, pro veřejnost... Takže my jsme se tady neměly jak rozvíjet... tak jsme si přibraly aktivity, pomáhaly paní ředitelce už s takovým tím papírováním - výkaznictví jsme si vzaly, koordinátora toho ICT - to všechno jsme my dvě 
(se současnou paní zástupkyní) takhle... I vysvědčení jsme poprosily paní ředitelku, aby nám dala už tisk, abychom nemusely psát rukou, protože nám to tady trošku vadilo, to pomalé tempo vývoje.

Ředitelka v rozhovoru uvedla, že koncepci školy tvořily a diskutovaly pouze se zástupkyní. Učitelé se $\mathrm{k}$ ní vyjádřit nemohli. Ředitelka opakovaně používá věty, které začíná slovy: „My s paní zástupkyní jsme rozhodly...“ At’ už se jednalo o prvotní koncepci školy, o volbu zaměření školy (inkluzivní vzdělávání), nebo bodovací systém pro zvýšení motivace žáků. Učitelky $v$ rozhovorech uvedly, že by rády o těchto záležitostech s vedením diskutovaly, ale nejsou $\mathrm{k}$ tomu přizvány. Rády by alespoň chápaly širší kontext a smysl změn. Některé učitelky vidí očividné chyby vedení v komunikaci, v nastavených pravidlech nebo rozhodnutích ohledně důležitých podmínek pro práci učitelek. Z pohledu učitelek: „Ta direktivita, to si myslím, že je úplně takový základní problém. "Vedení školy rozhoduje a učitelky vykonávají.

Většinu projektů vybírá vedení a přijde s tím jako s jasnou věcí. A asi většinou se $k$ tomu nemůžeme vyjádřit, jestli chceme, nebo nechceme. Prostě, jak se objeví nějaká akce, tak se snažíme do toho zapojit a myslím si, že už je toho hrozně moc... Jako většinou my tím, že je tady ta stará garda... tak to vezmem' a táhneme prostě, no, nandáme to na sebe... ale už je to takový, jako že... aby se nám nerozjely nohy za chvilku, jak máme naložený záda.

Několikrát bylo $v$ rozhovorech zmíněno, že vedení realizuje tzv. přepadové hospitace založené na sledování žákovských facebookových profilů. „Oni ji maj’ v přátelích, takže ona si to čte... To jsou takový informace, který... Vždycky pak jen koukáme, co se děje. Jo, chybí tam nějaká objektivita asi... Neříkám, že je to vědomý, myslím si, že prostě jim to spíš nedojde. “ Ředitelka na podněty žáků reaguje prímo hospitací, aniž s učiteli předem tyto podněty prohovoří.

Vedení školy pravděpodobně svoje pochybení nevidí. $K$ tomu zástupkyně:

Přijde mi, že oni si tam ty problémy trošku jako tvoří sami - něco se jim řekne, nějakým způsobem se má postupovat a oni nejsou moc jako... nevim ochotní nebo... jakoby... všechno tam tak jako rozebírají, převrtávají, přetáči - já si myslím, jo, přetáčejí a všechno chtějí, aby bylo jako po nich.

Vedení této školy se již šest let snaží o razantní změny. Na první pohled by se mohlo jednat o transformativní styl kombinovaný s instruktivním (vedení dochází na mnoho hospitací, hodnotí učitelky velmi kriticky). Jako klíčový problém v této škole se jeví, že vedení při nástupu do funkce neplánovalo změny společně se sborem ani sbor pro vizi školy nedokázalo získat, aby se zvýšila angažovanost učitelů a jejich oddanost organizaci. Vztahy mezi učiteli a vedením a mezi učiteli vzájemně jsou narušeny nedůvěrou, která je způsobena necitlivými zásahy vedení školy snižujícími profesní sebevědomí učitelů (např. přepadové hospitace inspirované žákovskou komunikací na facebooku). Ve škole se utvořily kliky, vedení s učiteli nediskutuje důležité otázky, které se jich týkají. Vedení školy chtělo školu transformovat, ale 
76 celé úsilí sklouzlo spiše k manažerismu (viz Pol, 2007b). Také se jeví, že vedení školy záleží spíše na vnějším obrazu školy (četné akce pro veřejnost, deklarované dobré vztahy s rodiči a žáky, dobré vztahy se zřizovatelem) než na vztazích mezi učiteli a vedením, mezi učiteli a žáky či učiteli navzájem. Vhodnými metodami vedení není podporována ani kvalita výuky, nebot' hospitace jsou velmi kriticky vedené a jsou výrazně formalizované. Vytvořila se situace, kdy se vedení školy a učitelé oddělili na skupiny my versus oni, přičemž v postoji k vedení nejsou ani učitelé zcela jednotní.

\subsection{ZŠ 158 - Škola, která „povstala z popela“ aneb Fénix mezi školami (příklad školy s vyváženým, demokratickým a transformativním stylem vedení)}

Výzkumná škola vykazovala na základě kvantitativního šetření velmi nepř́iznivé hodnoty sociálního klimatu učitelského sboru (112. z N =125). Škola se nachází v malé obci o přibližně 1500 obyvatelích, má asi 300 žáků a 25 učitelů. $V$ minulosti se potýkala s komplikovanými změnami ve vedení školy, které učitelský sbor destabilizovaly. Škola také začala ztrácet žáky, a to i přes poměrně příznivý demografický vývoj $\checkmark$ zemi. Učitelé se dělili na tábory stranící vybraným osobám. $V$ důsledku těchto komplikací došlo $\mathrm{k}$ velmi nepř́iznivému postoji tehdejších učitelů k nově jmenované paní ředitelce, která však regulérně vyhrála výběrové řízení na pozici. Škola za doby předchozích dvou ředitelů stagnovala z hlediska výuky, byla zadlužená a administrativní ř́zení ve škole téměř chybělo. Ředitelka uvádí: „Když jsem nastoupila, dostala jsem úplně prázdné počítače. Nikde ani šanon s informacemi.“

Ředitelka první dva roky ve funkci čelila devíti kontrolám od mnoha institucí - ČŠı (opakovaně), inspektorátu práce, hygieny a od obce. Všechny tyto kontroly proběhly na základě anonymních udání, s největší pravděpodobností od osob, které byly v minulosti zaměstnanci školy. Výsledky kontrol byly během dvou let ve funkci stávající ředitelky stále lepší. Ředitelka uvedla, že jak obec, tak Čšl konstatovaly, že další kontroly této školy nejsou $v$ nejbližších letech nutné.

Kvantitativní sonda (únor 2016) zachytila stav, kdy v učitelském sboru ještě pracovali učitelé stranící a učitelé nestranící nové paní ředitelce. Tento stav se během jednoho roku výrazně proměnil, nebot' postupně došlo $k$ obměně přibližně $70 \%$ učitelského sboru. $V$ současné době je situace ve škole stabilizována. Vedení školy nové učitele do sboru velmi obežretně vybírá s cílem v něm citlivě nastolit stabilní a převážně pozitivní klima. Podle výpovědí žáků jsou noví učitelé v této škole velmi dobří, žáci již v rámci výuky pocítili změnu $k$ lepšímu. Učitelé se $v$ rozhovorech shodli na tom, že ve škole panuje pořádek a $v$ práci se cítí bezpečně - vědí, co je od nich požadováno, komunikace od vedení je srozumitelná, někteří se do práce výslovně těší či přinejmenším nemají obavy z nečekaných nepříjemných změn či událostí. Z výpovědi paní učitelky s dlouholetou praxí v této škole: „Takové ty kolegiální vztahy toho člověka drží, ano? Ne vždy je člověk úspěšný v té práci ve třídě, protože ti žáci dovedou člověka vytočit, ale přijdeme do kabinetu, vracíme se tady s takovou jistotou... Tady mám bezpečí, to je důležité.“ 
Důležitým faktorem vedení je schopnost modelovat chování učitelů, být pro ně příkladem. Podle slov bývalé učitelky a současné asistentky pedagoga ve škole uvádí:

... to byly desítky, desítky a desítky hodin, kdy ona (paní ředitelka) tady trávívala $v$ té práci a všecko si to tady nějak $\mathrm{k}$ tomu svýmu obrazu přetvořila... protože když máte šéfa pracovitého a schopného, připraveného a s rozhledem, tak vlastně i vy se snažíte nějakým způsobem tady $v$ tomhle směru na sobě zapracovat.

$Z$ další výpovědi této zaměstnankyně vyplynulo, že je ředitelka kvalitní pedagožka, dokáže školu pozdvihnout a inovovat její činnost. „Ta škola jako by rozkvetla najednou... zase už je tady př́růstek těch žáků, projekty, do kterých se zapojujeme, i ta naše image vúči veřejnosti, no, a samozřejmě ta kvalita vzdělávání... je to taková naše každodenní práce.“ V souvislosti s vizí školy byl inovován školní vzdělávací program. Učitelé na něm pracovali týmově pod vedením určených garantů. Zásadní změnou $v$ něm bylo nastavení mezipředmětových vztahů $v$ učivu nebo zavedení anglického jazyka již od 1. ročníku.

Ředitelka zavedla dvě povinná školení ročně pro každého učitele ve škole. Učitelé však mají svobodu při výběru školení, které jim a jejich žákům bude $k$ užitku. Takto vedení školy podporuje jak vizi školy, tak individuálně učitele. Individuální př́stup lze spatřovat také ve volnosti stanovených konzultačních hodin učitelů pro rodiče, které si učitelé volí podle svých časových možností, nebo $v$ dobrovolnosti účastnit se společných aktivit učitelů. Zohlednění cílů školy jako vzdělávací instituce a zároveň cílů a individuálních potřeb učitelů významně přispívá $\mathrm{k}$ příznivé situaci $z$ hlediska klimatu ve sboru.

Ředitelka učitele pravidelně zve $\mathrm{k}$ dobrovolné účasti na teamspiritových aktivitách, probíhají pravidelně oslavy narozenin, den učitelů, výlety apod. Běžně se zapojují také rodinní př́slušníci učitelů a další personál školy. Dále zavedla vzájemné hospitace učitelů. Říká: ,...není ostuda, když se ti hodina nepovede, mně se také někdy nepovede, ale vzájemně si to vykomunikujete neformálně, co je a co není dobré ve výuce dělat. “Čili hospitace probíhají převážně neformálně, bez zápisů a cílem je vzájemné učení kolegů. Vzájemné učení kolegů provozují také učitelé mezi sebou. Nejen uvádějící učitelé zvou své nové kolegy do svých hodin, ale také stávající učitelé navzájem.

... snažíme se právě vždycky na tu hodinu připravit něco zajímavého, co by se ten druhý mohl naučit z toho, že ne jen klasická hodina, jak prostě ta hodina je, že děláme prostě třeba gramatiku nějakou, že to je takové jako nezáživné, ale že se snažíme třeba i nějakou jinou aktivitu... aby se ten druhý poučil a zkusil to třeba ve své hodině.

Ředitelka po nástupu do funkce začala řešit problémy, které „,hořely“. Zaměřila se zprvu na administrativu, protože, jak uvedla: „...škola byla v totálním rozkladu.“ Postupně zvládla všechny kontroly, vyrovnala se s nejhoršími problémy ve škole (zpronevěra, zaevidované, ale chybějící drahé pomůcky, velká nemocnost učitelů) a zaměřila se na získávání kvalitních pracovníků. Díky dobrovolným aktivitám pro podporu dobrých vztahů, uznání odbornosti učitelů (společně tvoří vizi školy) a inte- 
78 lektuální stimulaci stoupají angažovanost učitelů a oddanost škole. Služebně i věkem starší kolegové do jisté míry stagnují, viditelně pomaleji akceptují změny, ale pokud jsou schopni alespoň částečných změn, jsou dostatečně ve sboru přijímáni.

Ředitelka si je vědoma svého perfekcionismu, a také proto naslouchá současné zástupkyni, kterou si pozvala ke spolupráci ze své bývalé střední školy, kde obě vyučovaly. Zástupkyně do jisté míry „uzemňuje“ vizionářství paní ředitelky. Volba zástupkyně byla kličová pro narovnání vztahů mezi učiteli, protože zástupkyně dokáže klidně a s rozmyslem řešit situace, ve kterých by ředitelka již byla príliš emotivní. Obě tuto situaci chápou a společně lépe zvládají strategii vedení školy.

Ředitelka dokázala na začátku rozlišit změny prvního a druhého řádu a její styl vedení se hned od začátku blížil „vyváženému vedení“. Například v dimenzi „kultura školy“ (viz Waters et al., 2003, s. 9) nejenom podpořila kooperaci učitelů a snaží se o kohezi (vybírá vhodné pracovníky do sboru a nabízí teamspiritové programy), ale také se zabývala sdílením vize za účelem porozumění záměru, který měla (změna ŠVP). V dimenzi „zdroje“ (tamtéž) byla schopna nejen zajistit materiální podmínky a vybavení, ale zároveň poskytnout učitelům další vzdělávání k získání dovedností k jejich používání. Podobně dokázala odlišit odměňování, podílení se na rozhodování školy, změny statu quo, a dokonce je schopna jít nad rámec fungování školy a otevřít ji dalším výzvám - škola jako kulturní centrum (škola např. organizuje koncerty v místním kostele). Vedení zavádí velké změny ve škole, rychle a efektivně, ale nezapomíná na potřeby zaměstnanců a jeho flexibilita jde ruku v ruce se zachováním hodnot a smyslu.

Ředitelka dala učitelům důvěru a učitelé mohli pracovat týmově (distributivní prvek). Vedení velmi vítá iniciativu učitelů a jejich názorům a nápadům naslouchá. Péče o začínající učitele je velmi dobrá. Velmi záhy ředitelka porozuměla potřebě „udělat něco pro lidi“, „,naslouchat názorům druhých“ a začala k učitelům i ostatním pracovníkům ve škole přistupovat demokraticky. Vedení v této výzkumné škole v současné chvíli postupně pozbývá prvků „krizového managementu“ a nabývá charakteristik demokratického a transformativního vedení s prvky distributivního rízení. Za klíčové nyní vedení školy považuje sdílení vizí a hodnot v organizaci, které diskutuje s učiteli i ostatními zaměstnanci školy, částečné rozdělení vedení (ředitelka dala volnost minitýmům reformulovat ŠVP podle vize), investice do rozvoje zaměstnanců (povinná dvě školení ročně, možnost dalšího vzdělávání pro zájemce), budování mezilidských vztahů (teamspiritové aktivity, vhodná a otevřená komunikace) a budování školy jako učící se komunity (sdílená praxe učitelů, vzájemná inspirace a vzájemné neformální hospitace) přesně tak, jak je tento styl vymezen shora. Také učitelé dle jejich výpovědí tuto atmosféru důvěry vnímají a jejich chování vưči vedení i mezi sebou tomu odpovídá.

\section{3 Škola s pevně prosazovanou vizí (příklad školy s transformativním a na lidi orientovaným vedením)}

Škola má přibližně 500 žáků a 28 učitelů a nachází se ve městě s 28000 obyvateli. Ve škole bylo klima učitelského sboru opakovaně měřeno v letech 2003, 2013 a 2016 
a vykazuje po celou dobu stejné, velmi přiznivé charakteristiky, a můžeme ho proto označit jako otevřené (Hoy et al., 1991, s. 33). V roce 2016 se mezi školami umístila na 15. místě z $N=125$, v druhém nejlepším shluku z pěti z hlediska otevřenosti klimatu.

$\checkmark$ čele školy stojí ředitel, který tuto funkci vykonává již 26 let, po celou dobu fungování školy. Širší vedení dále tvoří zástupkyně ředitele, výchovná poradkyně a dva neformální vedoucí učitelů. Řediteli šlo od počátku jeho působení ve škole o zavádění netradičních, alternativních přístupů, a zároveň chtěl, aby škola byla určena všem dětem a nestala se školou alternativní. Poptávka po službách školy $v$ současnosti výrazně převyšuje možnosti její kapacity, zatímco ve městě v průběhu let dvě školy postupně zanikly.

Zásadní význam pro školu a její fungování má vize školy, jejímž primárním nositelem je ředitel. Je založena na hodnotě školy jako služby pro rodiče a jejich děti, na partnerských vztazích a kvalitní výuce. Ředitel pojetí služby rodičům a dětem nechápe jako podbízení se, či dokonce jako slevování požadavků z kvality výuky a studijních výsledků žáků, jak ukazují jeho slova:

\begin{abstract}
Služba, ne služka, já nedělám (dưraz) všechno, co chtěj' rodiče, jsou věci, o kterejch s rodiči nediskutuju, nebo takhle - diskutuju s nimi o všem, ale my (důraz) jsme vystudovaní, my se vzděláváme, my víme, proč jsme zavedli Hejnýho matiku, my víme, proč jsme zavedli Comenia Script, my víme, proč učíme kooperativně, my víme, proč máme slovní hodnocení na 1. stupni a já vám to rád budu vysvětlovat, ale nebudu to kvưli vám měnit. A když něco zavádíme, tak to maj' všechny (důraz) děti, ne, že áčko bude mít Comenia Script a béčko bude psát takhle. Tohleto je náš program, tohleto nabízíme, berte, nebo nechte být.
\end{abstract}

Stejně pevně prosazuje ředitel svou vizi i v učitelském sboru. Někteři učitelé ze školy odešli, protože nebyli ochotni tuto vizi přijmout. Ředitel je na jedné straně sice př́stupný diskusi s rodiči i učiteli, na druhé straně se jeho přesvědčení a hodnoty staly pevným základem jeho vedení a života celé školy. Tyto hodnoty jsou primárně morální, nebot' se týkají spokojenosti a pohody učitelů i žáků a mezilidských vztahů. Výstižně to vyjadřuje zástupkyně školy: „Ředitel žije školou, žije, on tady stráví opravdu strašně (důraz) moc hodin, tou školou žije a pro tu školu a pro ty děti vymejšlí a pro učitele vymejšlí, aby byli v pohodě.“

S hodnotami a vizemi školy úzce souvisí i vnímání podstaty funkce ředitele a učitelů, jak je formuloval při rozhovoru ředitel: ,....až po tom jsem si to tak ňák formuloval pro sebe, $\mathrm{k}$ čemu je ve škole ředitel. Ředitel tam je proto, aby vytvořil optimální podmínky pro práci učitelů. Proč tam jsou učitelé? Aby vytvářeli optimální podmínky pro výchovu a vzdělávání svých žáků.“

Za zásadní lze považovat, že po učitelích vyžaduje především kvalitní práci s dětmi během vyučování. Učitelé nemusí vést např́iklad žádné kroužky, tato činnost je pouze dobrovolná. Nemají na starosti ani administrativní a organizační činnosti nad rámec výuky. Pro ředitele jsou potřeby lidí ve škole důležitější než potřeby organizace, administrativa nebo striktní dodržování vyhlášek a předpisů.

Ředitel klade důraz také na další vzdělávání učitelů. Kromě individuálního vzdělávání každoročně pořádá výjezdní školení pro celý učitelský sbor k tématům, která 
80 mohou školu posunout dál. Cílem těchto akcí je kromě vzdělávání také rozvíjení dobrých vztahů mezi učiteli a podpora jejich spolupráce. Ředitel usiluje dále o podporu profesního sebevědomí učitelů tím, že s nimi diskutuje odborné problémy a často přijímá jejich návrhy řešení. Podporuje je rovněž v lektorské činnosti.

Ředitel je učitelům pozitivním príkladem nejen svým zápalem pro práci, ale i svou otevřenou komunikací. Učitelé ho vnímají jako součást sboru, jak vyplývá ze slov jedné z učitelek:

Stejně jako sebe jako učitele vnímám, že jsem mezi těma dětma, tak i toho ředitele, pokud to má dobře fungovat, vnímám, že je mezi těmi učiteli. Jestli mi rozumíte, jak to myslím, ale pro mě právě je důležité to, že náš pan ředitel je (důraz) mezi tim součástí toho sboru. Není to ředitel a učitel, ale je to ten sbor přesně, jak jste to popsal.

Ředitel si při transformaci školy určil jako prioritu budovat dobré vztahy mezi učiteli. Tento cíl se mu daří naplňovat, jak potvrdili všichni učitelé, s nimiž jsme vedly rozhovory. Učitelé společně řeší profesní problémy a spolupracují při plnění komplexnějších úkolů. Společně sdílejí materiály a pomůcky $\mathrm{k}$ výuce, které získali na školeních nebo si sami vyrobili, využívají i vzájemných hospitací.

$Z$ uvedené analýzy je patrné, že ředitel školy uplatňuje dlouhodobě transformativní styl vedení. Naplňuje charakteristiky tohoto stylu uvedené v Leithwoodově modelu (cit. podle Hallinger, 2003). Za rizika tohoto stylu Bush a Glover uvádějí, že může být použit jako prostředek $\mathrm{k}$ manipulaci nebo kontrole učitelů, kteří jsou povinni podporovat „vizi“ a cíle vůdce (2014), a to ovlivňuje někdy žádoucí diverzitu názorů a př́stupů. Toto riziko se však $v$ této škole uplatnilo jen částečně. Učitelé, kteři v minulosti nebyli schopni vizi přijmout, ze školy odešli. $V$ současné době ve škole pracují učitelé, kteři se s danou vizí plně ztotožňují a dokážou ji ve své práci uskutečňovat. Ředitel je na jedné straně pevný a zásadový v prosazování hodnot a vize školy, na druhé straně podporuje participaci učitelů na dalším rozvoji školy, přijímá jejich názory a návrhy, je otevřený diskusi.

Transformativní styl vedení je kombinován s vedením orientovaným na lidi, nebot' kvalitní partnerské vztahy byly od počátku pro ředitele prioritní hodnotou i cílem jeho vedení. Ředitel stojí v centru učitelského sboru a modeluje chování, které očekává od učitelů. Pracuje pro školu s plným nasazením, snaží se vytvářet nadstandardní podmínky pro práci učitelů a očekává, že učitelé budou totéž poskytovat svým žákům. Kvalita vztahů se pozitivně promítá do klimatu učitelského sboru a celkové spokojenosti učitelů vyjádřené velmi nízkou hodnotou frustrace. Ředitel je také dobrý manažer a dokáže své vize realizovat $\mathrm{v}$ každodenním chodu školy.

\section{Diskuse}

Manažerský styl je považován pro vedení školy za nezbytný, nebot' zajišt'uje samotné fungování školy a každodenní provoz. Ve vztahu ke změnám je nepostradatelný pro jejich zavádění do praxe. $V$ jedné $z$ našich výzkumných škol však tento styl zůstal 
osamocen bez spojitosti s hodnotami a vizemi školy. Prostředky manažerského vedení (formuláře, hospitační archy, kontrola učitelů, dokumentace) se ve škole „s nepřijatým vedením“ staly samoúčelnými cíli. Tento manažeristický způsob vedení vedl u učitelů k odklonu od vedení školy, k zvýšenému pocitu frustrace a k vzájemné ztrátě důvěry. $V$ obou dalších školách jsme nalezly také snahu o zvládnutí manažerských povinností vedením školy, nicméně nedošlo k oddělení prostředků manažerského vedení s vizí a hodnotami. Příkladem je práce vedení ve škole „s nepřijatým vedením“ a ve škole, „která povstala z popela“. V obou školách se vedení na začátku svého působení pustilo do práce na vytvoření dokumentace a propracovalo prostředky manažerského vedení. Zatímco však v prvně jmenované škole vedení vize a hodnoty $s$ učiteli nesdílelo, $v$ druhé škole se učitelé více podílí i na koncepčních změnách.

Styly instruktivní a transformativní mají v centru pozornosti procesy změny výuky a školy. Instruktivní styl je zaměřen na kvalitu výuky a její změny, zatímco transformativní styl je komplexnější a je cílen kromě změny vyučování i na oblasti, jako jsou změna kultury školy, vztahy s veřejností, vztahy v učitelském sboru nebo změny v charakteristikách vedení školy. Ve škole „s pevně prosazovanou vizi“ se ukázalo, že pro úspěšnou transformaci této školy byly klíčové sdílené hodnoty a na nich založené vize, které přijímá celý učitelský sbor. Dalším zjištěním bylo, že změny druhého řádu se výrazněji projevily $v$ delším časovém horizontu (dle ředitele zhruba po osmi letech). Př́kladem takových změn v této škole je transformace mezilidských vztahů na všech úrovních založená na otevřené komunikaci a vzájemné dưvěře nebo kooperativní vyučování ve všech třídách.

Jak je popsáno v teorii vyváženého vedení, změny prvního řádu zachovávají status quo školy, zatímco změny druhého řádu zasahují hlouběji a mění paradigma školy. Transformující se školy často zůstávají u změn prvního řádu, nebot' jsou snadnější, rychleji realizovatelné a viditelné. Často je mohou volit školy, jejichž zájem směřuje k dobré prezentaci na veřejnosti. Mají co ukázat (nové vybavení, atraktivní učební plán), nicméně ve skutečnosti zůstávají u původních hodnot a postupů. Toto vystihuje př́klad školy „s nepřijatým vedením“, ve které se ředitelka zaměřila na vnímání školy veřejností, nikoli na klima v učitelském sboru a mezi žáky. Vyžadovala od učitelů velké množství akcí nad rámec výuky, čímž je přetěžovala a odváděla od zlepšování vyučování. Př́iklady vyváženého vedení jsou uvedeny $v$ rámci studie školy, „která povstala z popela“, v níž jsme zaznamenaly začátky snahy o koncepční změny ve škole. $V$ třetím případu školy „s pevně prosazovanou vizi“ jsme naopak zachytily stav dlouhodobě prosazovaných změn, které takřka již vrostly do celkové kultury školy.

Distributivní styl vedení akcentuje oblast participace učitelů na vedení školy a jejich zapojení do řízení změn. Neznamená však pouhé delegování činností ředitelem na učitele, ale přenesení pravomocí a odpovědnosti. Tento styl považuje zkvalitňování výuky a celkovou transformaci školy za samozřejmé. V ohnisku zájmu je vysvětlení, proč je důležité, aby moc byla rozdělena i mezi učitele. Důvodem pro formulování tohoto přístupu k vedení byly výzkumné nálezy, které ukázaly, že ředitelé nemusí vždy být experty na výuku nebo jiné činnosti školy. Distributivní styl 
82 v našich výzkumných školách nenacházíme $v$ jeho čisté podobě, protože ho nejspiš neumožňuje česká školská legislativa. Pravomoci a odpovědnost za chod školy má podle ní pouze ředitel, a proto musí mít nad děním ve škole naprostou kontrolu. Proto v našich výzkumných školách nalézáme spíše příklady demokratického a na lidi orientovaného stylu vedení, které zdůrazňují v mezilidských vztazích hodnoty, jako jsou respekt, rovnoprávnost lidská i názorová, tolerance $k$ diverzitě názorů i př́stupů k vyučování. Tento styl vedení se projevuje v oboustranné a otevřené komunikaci mezi vedením a učiteli a $v$ ochotě vedení školy akceptovat názory učitelů. Prvky distributivního stylu nacházíme spiše $v$ aktivitách učitelů, které se týkají prostředí školy a samotné výuky než v činnostech, za které ze zákona odpovídá ředitel. Příkladem je škola, „která povstala z popela“, v níž učitelka samostatně vybudovala školní knihovnu a vede $v$ ní čtenářské dílny nebo jiná učitelka výtvarně vyzdobila společné prostory školy.

Jak se $v$ našem výzkumu ukázalo, každý styl vedení je zaměřen jen na určitý výsek reality, zatímco sama realita je komplexní. Ukazuje se také, že jedním z nejdůležitějších faktorů pro volbu stylu vedení je situace školy čili kontext, ve kterém se škola právě nachází, zda je škola v situaci, kdy změny připravuje, začíná realizovat, anebo je ve stadiu stabilizace změn. $S$ tím souvisí situace $v$ učitelském sboru, jestli je sbor stálý, nebo se učitelé často proměňují. Důležitý faktor je také složení žáků a jejich dostatek či nedostatek. Kontext tvoří vztahy se zřizovatelem, legislativa a školská politika státu. Ve škole „s pevně prosazovanou vizi“ se stabilita sociálního klimatu učitelského sboru pojí s dlouhodobým působením jednoho ředitele a stabilními hodnotami a vizí školy. $V$ obou dalších školách nalézáme velké obměny sboru s príchodem nového vedení. Ve škole „s nepřijatým vedením“ vedení školy přináší nové vize, ale neumí je dobře komunikovat s učiteli, zatímco ve škole, která „povstala z popela“, byli učitelé do tvorby vizí zapojeni. Jeví se, že ředitelé těchto dvou výzkumných škol pravděpodobně inklinují k intuitivní volbě stylu vedení, aniž by vždy byli schopni přizpůsobit procesy vedení kontextu konkrétní situace, v níž se škola nachází. Ve škole „s dlouhodobě prosazovanou vizi“ naopak nalézáme jasnou vizi a koncepci, prosazovanou jednotným a dlouhodobě stejným stylem.

$\mathrm{Na}$ výzkumnou otázku: Jaké styly vedení se vyskytují ve vybraných školách s extrémními parametry sociálního klimatu učitelských sborư? - jsme se pokusily odpovědět již $v$ prededchozí kapitole $v$ rámci jednotlivých príběhů škol. Ve výzkumných školách jsme nalezly spíše kombinace stylů vedení s různými dopady na reálnou situaci ve škole především z hlediska sledovaného klimatu. Školy se špatnými parametry sociálního klimatu sboru se obě nacházely v situaci významných změn. Kvalitní klima třetí výzkumné školy bylo pravděpodobně způsobeno dlouhodobým, jednotným a čitelným působením vedení školy. Jako kličové se zde jeví hodnoty jako důvěra v mezilidských vztazích, respekt k názorové diverzitě, která nenarušuje základní vizi školy a schopnost dohody a spolupráce. Jako podstatné se dále ukázalo postavení ředitele uprostřed učitelského sboru modelujícího svým jednáním angažovaný př́stup k práci. Takové modelování jsme nalezly také ve škole, „která povstala z popela“, ve které si však učitelé na styl vedení paní ředitelky teprve zvykají. $V$ těchto dvou 
školách vedení důvěřuje svým učitelům a přenáší na ně část odpovědnosti, nemá potřebu jejich neustálé kontroly a nevyžaduje rozsáhlou administrativu a dokumentování všech jejich činností. Učitelé si pak takového ředitele váží jako přirozené autority a důvěřují mu.

Z našich výzkumných nálezů vyplývá, že pro praxi není úplně výhodné rozlišovat jednotlivé styly vedení pomocí přidaných adjektiv. Pro popis reality ve školách je třeba hledat komplexnější a obecnější model, který by dokázal vzít $v$ úvahu kontext školy a důležité oblasti vedení, jako jsou např́iklad hodnoty a dlouhodobé vize školy, kvalita vyučování, kvalita mezilidských vztahů, oblast spolupráce a sociálního klimatu ve sboru, vztah vedení školy a sboru, řízení změn (prvního i druhého rádu), uplatnění distribuce vedení a nastavení školy jako učící se organizace.

\section{Literatura}

Bass, B. M. (1985). Leadership and performance beyond expectations. New York: The Free Press.

Bolden, R. (2011). Distributed leadership in organizations: A review of theory and research. International Journal of Management Reviews, 13(3), 251-269.

Bush, T. (2013). Distributed leadership. Educational Management Administration \& Leadership, 41(5), 543-544.

Bush, T., \& Glover, D. (2012). Distributed leadership in action: Leading high-performing leadership teams in English schools. School Leadership \& Management, 32(1), 21-36.

Bush, T., \& Glover, D. (2014). School leadership models: What do we know? School Leadership \& Management, 34(5), 553-571.

Day, Ch., Sammons, P., Hopkins, D., Harris, A., Leithwood, K., Gu, Q., ... Kington, A. (2009). The impact of school leadership on pupil outcomes: Final report. Nottingham: Department for Children, Schools and Families.

Hallinger, P. (2003). Leading educational change: Reflections on the practice of instructional and transformational leadership. Cambridge Journal of Education, 33(3), 329-352.

Hallinger, P., \& Heck, R. (1996). The principal's role in school effectiveness: a review of methodological issues, 1980-1995. In K. Leithwood et al. (Eds.), The international handbook of educational leadership and administration (s. 723-784). Dordrecht: Kluwer.

Harris, A. (2003). Teacher leadership as distributed leadership: Heresy, fantasy or possibility? Educational Management Administration \& Leadership, 23(3), 313-324.

Harris, A. (2004). Distributed leadership and school improvement. Educational Management Administration \& Leadership, 32(1), 11-24.

Harris, A. (2005). Distributed leadership. In B. Davies (Ed.), The essentials of school leadership (s. 160-172). London: Paul Chapman.

Harris, A., \& Chapman, C. (2002). Democratic leadership for school improvement in challenging context. International Electronic Journal for Leadership in Learning, 6(9), 1-12.

Hendl, J. (2005). Kvalitativní výzkum: Základní metody a aplikace. Praha: Portál.

Hoy, W. K., Tarter, C. J., \& Kottkamp, R. B. (1991). Open schools / healthy schools: Measuring organizational climate. Beverly Hills: Sage.

Chvál, M., \& Urbánek, P. (2014). Klima učitelského sboru: Úprava dotazníku OCDQ-RS pro podmínky českých škol. Pedagogická orientace, 24(5), 778-803.

Kirkbride, P. (2006). Developing transformational leaders: The full range leadership model in action. Industrial and Commercial Training, 38(1), 23-32.

Leithwood, K., \& Jantzi, D. (2005). A review of transformational school leadership research 1996-2005. Leadership and Policy in Schools, 4(3), 177-199. 
84 Leithwood, K., \& Riehl, C. (2003). What do we already know about successful school leadership? Washington: AERA.

Lumby, J. (2013). Distributed leadership the uses and abuses of power. Educational Management Administration \& Leadership, 41(5), 581-597.

Mareš, J. (2015). Tvorba případových studií pro výzkumné účely. Pedagogika, 65(2), 113-142.

Pol, M. (2007a). Škola vedená, řízená a spravovaná. Pedagogika, 57(3), 213-226.

Pol, M. (2007b). Škola v proměnách. Brno: MU.

Pol, M., Hloušková, L., Novotný, P., \& Sedláček, M. (2010). Profesní dráha ředitelů základních škol: Od fáze profesní jistoty k novým výzvám. Studia paedagogica, 15(1), 85-105.

Pol, M., Hloušková, L., Novotný, P., \& Sedláček, M. (2013). Když se školy učí. Brno: MU.

Pol, M., Hloušková, L., Novotný, P., \& Zounek, J. (2005). Kultura školy. Příspěvek k výzkumu a rozvoji. Brno: MU.

Rhodes, C., \& Brundrett, M. (2010). Leadership for learning. In T. Bush, L. Bell, \& D. Middlewood (Eds.), The principles of educational leadership and management (s. 153-175). London: Sage.

Sedláček, M. (2011). Pedagogické vedení školy v pojetí ředitelů základních škol. Orbis scholae, 5(3), 27-43.

Šed’ová, K., Švaříček, R., Sedláček, M., \& Šalamounová, Z. (2016). Jak se učitelé učí: Cestou profesního rozvoje $k$ dialogickému vyučování. Brno: MU.

Švařriček, R., Šed’ová, K., Janík, T., Kaščák, O., Miková, M., Nedbálková, K., ... Zounek, J. (2007). Kvalitativní výzkum v pedagogických vědách. Praha: Portál.

Urbánek, P., Dvořák, D., \& Starý, K. (2014). Dynamika sociálního klimatu učitelských sborů $\checkmark$ době reformy. Orbis scholae, 8(1), 65-78.

Vanblaere, B., \& Devos, G. (2016). Relating school leadership to perceived professional learning community characteristics: A multilevel analysis. Teaching and Teacher Education, 57, 26-37.

Vanderhaar, J. E., Muñoz, M. A., \& Rodosky, R. J. (2007). Leadership as accountability for learning: The effects of school poverty, teacher experience, previous achievement and principal preparation programmes on student achievement. Journal of Personnel Evaluation in Education, 19(1, 2), 17-33.

Waters, T., Marzano, R., \& McNulty, B. (2003). Balanced leadership: What 30 years of research tells us about the effect of leadership on student achievement. A working paper. Denver: MCREL.

Mgr. Andrea Rozkovcová, Ph.D.

Fakulta prírodovědně-humanitní a pedagogická, Technická univerzita v Liberci Univerzitní náměstí 1410/1, 46117 Liberec andrea.rozkovcová@tul.cz

PhDr. Jitka Novotová, Ph.D.

Fakulta prírodovědně-humanitní a pedagogická, Technická univerzita v Liberci Univerzitní náměstí 1410/1, 46117 Liberec jitka.novotova@tul.cz 